\title{
Article
}

\section{Truth and Reconciliation: a welcome dialogue}

Spandler, Helen and Mckeown, Michael

Available at http://clok.uclan.ac.uk/20452/

Spandler, Helen ORCID: 0000-0002-0970-5141 and Mckeown, Michael ORCID: 0000-0003-0235-1923 (2017) Truth and Reconciliation: a welcome dialogue. Mental Health Review Journal . ISSN 1361-9322

It is advisable to refer to the publisher's version if you intend to cite from the work. http://dx.doi.org/10.1108/mhrj-10-2017-0045

For more information about UCLan's research in this area go to http://www.uclan.ac.uk/researchgroups/ and search for < name of research Group>.

For information about Research generally at UCLan please go to http://www.uclan.ac.uk/research/

All outputs in CLoK are protected by Intellectual Property Rights law, including Copyright law. Copyright, IPR and Moral Rights for the works on this site are retained by the individual authors and/or other copyright owners. Terms and conditions for use of this material are defined in the policies page.

\section{CLoK}

Central Lancashire online Knowledge www.clok.uclan.ac.uk

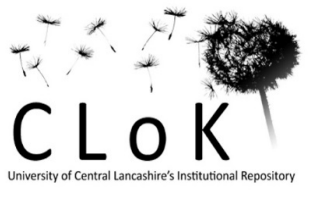




\section{Truth and Reconciliation}

\section{A welcome dialogue: a response to Mark Cresswell}

\section{Mental Health Review Journal}

Pre-publication version

Helen Spandler and Mick Mckeown

Email: Hspandler@uclan.ac.uk

At the outset we'd like to thank Mark Cresswell for taking the time to carefully read and respond to our case for a grassroots Truth and Reconciliation (T\&R) process in psychiatry. We appreciate the opportunity provided by the editors to reply in kind and hope this exchange represents the kind of respectful dialogue we seek going forward. We are pleased that our paper has encouraged such discussion (see also Carr and Taggart 2017). We will try to respond to each point Mark raises, in turn.

The first criticism is that we blur the boundaries between contemporary and historical abuses in psychiatry and that our advocacy of T\&R rests on forced psychiatry within an asylum system of care. On the first point, we believe the boundaries between historical and contemporary mental health systems are blurred, for precisely the reasons Mark highlights i.e. that coercion continues in post asylum based mental health systems, both within psychiatric units and the community. Therefore, there has been no clear historical 'break' between an oppressive asylum system and a nonoppressive post asylum system. We thoroughly appreciate the complexity of contemporary psychiatry but believe that psychiatry has always been complex, diverse and multi-faceted. Therefore, we accept that the continuation of coercion in psychiatry complicates any simple demarcation of a pre and post oppressive system.

However, on the second point, that would only be a problem if our calls for T\&R rested solely on the basis of historical abuses in the asylum system, which it doesn't, for the reasons above. Having said that, even if it did, historical abuse would be more than a good enough reason for a post asylum process similar to post-apartheid T\&R. However, we think the need for T\&R is twofold: to apologise for and understand past abuses, but also to contribute to an understanding, and prevention of, contemporary abuses and harm. We absolutely agree that this process would need to involve the broad range of mental health professionals, not just hospital-based psychiatrists and nurses. For this reason, we have talked to a range of professional groups about this process (including Approved Mental Health Practitioners, Community Psychiatric Nurses and other health workers involved in UNISON, the UK public sector trade union). Where possible, we have presented these ideas alongside service users, such as Jan Wallcraft, who was one of the first people to initiate this idea.

Mark also suggests the lack of judicial status that would accompany formal T\&R will mean mental health workers will be less willing to engage in it. Whilst that may be true, it may also work the other way round i.e. its voluntary nature might foster engagement, precisely because it is not a topdown initiative. On the other hand, we think the lack of formal sanction is more likely to effect the willingness of mental health users and survivors to engage with it. They may (reasonably) fear that it 'won't make any difference anyway' and psychiatry cannot, or will not, apologise, or be held accountable. Whilst this is also a fair point, a grassroots T\&R process might actually help to build $a$ case for a more formally sanctioned process. 
We agree with Mark that the workers most likely to engage with T\&R would be those already recruited to the survivor movement's cause. However, this is probably the case for any progressive social initiative. At least in their early stages, social movements are initiated by people committed to the cause but, if effective, they are gradually able to involve more people through various organising activities.

On the one hand, whilst we appreciate the concern that we may be 'preaching to the converted', this notion rather misunderstands the essence of T\&R initiatives. Whilst it is necessary to foreground survivors' testimony, it is not about 'preaching' but about listening, understanding and learning. T\&R is about dialogue, not monologue. This is part of consciousness raising, an essential component of any progressive initiative for social change. Indeed, the forms of dialogue envisioned within T\&R may not be so far removed from the sorts of discussions that are part of effective campaigning.

Therefore, it is precisely this kind of mutual learning that could result wider participation and engagement. Contrary to the idea that workers are unlikely to support it, we have actually found at least some support for this kind of initiative amongst a range of mental health workers we have consulted. Whilst they might not be completely signed up to a radical survivor agenda, they often have broad sympathies with the plight of service users and survivors and may be open to change. In addition, increasing acceptance of the principles of trauma informed care, could open up recognition by staff of their complicity in harms, such as re-traumatisation in the system, but also their ability to provide compassionate support and understanding.

In our advocacy for T\&R as a form of restorative social justice, Mark is worried we have given up too quickly on more substantive forms of retributive justice and legal reform. Whilst we admit we may be frustrated with the slow pace of change, and would like to see more progress in our lifetime, we have not completely given up on wider reforms or social justice. Moreover, we don't think restorative justice and campaigning for wider social changes are incompatible strategies, but we see them both as important and necessary. Indeed, we see them as complementary and potentially mutually reinforcing. In other words, T\&R could actually be part of a broader movement for social change, not an alternative to it. This is why we see it as a transitional form of justice.

Without fuller acknowledgement of psychiatric harm, it will continue to be difficult to make the case for wider social change. Similarly, without wider public recognition of harms, and without more progressive social policies, it is difficult to make progress within or beyond the psychiatric system. More importantly, unless any wider social changes are informed by a fuller appreciation of the depth and breadth of survivor grievances, they may just reproduce the same problems in new forms. Having said all that, we wouldn't put all our eggs in the T\&R basket, and we certainly don't assume that all survivors, service users and workers should (or would want to) participate in such a process either.

Mark's final criticism rests on an apparent contrast between consensus versus antagonism as the key driver for social change. Mark is concerned about our optimistic bias towards consensual and reconciled outcomes which he argues could effectively undermine democracy. In this argument. democracy necessarily entails antagonism and identifying demarcated 'enemies'. Whilst he is right to highlight this as an important point of emphasis, we think it is probably an unhelpful distinction in practice. Whilst it may be possible to make this distinction theoretically, we do not believe this is an abstract theoretical question, but a concrete practical one.

Reconciliation does not necessarily mean agreement or acquiescence. There is no reason why T\&R processes can't involve disagreement, debate and contestation. Whilst it would hopefully involve a 
deeper understanding of different perspectives, it doesn't necessarily demand consensus. Indeed, it might actually involve a greater toleration of difference and diversity, which is an important quality to foster if we are to create better responses to mental distress, which must be our ultimate aim. Outcomes of a more deliberative democracy may be actually plural, and desirably so; for example, contemplation of a range of alternative care and treatment options beyond narrow bio-psychiatry. Rather than unanimity, a T\&R process may at least establish more civil foundations for currently contentious discussions, which is necessary if we are to build movement alliances.

Nevertheless, whilst testimony as a form of political activism doesn't have to involve reconciliation and certainly not as an imperative - we don't think it should preclude it either. Conflict is already at the heart of psychiatry, and it is true that any tensions are likely to be reproduced in any micro social settings designed to resolve or attend to its effects. Reaching common cause may be a long term objective, with a rocky road ahead. However, fuelling antagonistic and adversarial relationships, especially between workers and service users, does not benefit either. Instead we would rather put our energies into forging alliances, especially in the current context where mental health services are under attack and, in the absence of alternatives, coercive and potentially harmful interventions become even more prevalent.

Reconciliation may, or may not, be the outcome of any particular T\&R process. However, ultimately, it may be a necessary condition for more humane mental health services and relationships. Thus our case for T\&R is inseparable from our belief in the possibility of more consensual and mutual support systems. In other words, to adapt a phrase from anti-capitalist activism, we believe that better mental health services are possible. This belief lies at the root of our optimism. It is clear from Mark's critique, and his previous work, that he shares our commitment to a progressive politics of mental health based on alliances between workers and service users. In this respect his response is helpful in moving dialogue forward. We believe that T\&R is one means amongst many for making a positive contribution to this project. We hope Mark and other interlocutors will continue to join this dialogue.

\section{References}

Carr, S, and Taggart, D. (2017) Do we need a truth and reconciliation process in psychiatry? https://www.nationalelfservice.net/populations-and-settings/service-user-involvement/do-weneed-a-truth-and-reconciliation-process-in-psychiatry/ 